ISSN 1392-3196 / e-ISSN 2335-8947

Zemdirbyste-Agriculture, vol. 105, No. 3 (2018), p. 265-270

DOI 10.13080/z-a.2018.105.034

\title{
Genetic diversity of Botrytis cinerea from strawberry in Lithuania
}

\author{
Neringa RASIUKEVIČIŪTĖ, Rytis RUGIENIUS, Jūratė Bronė ŠIKŠNIANIENĖ \\ Institute of Horticulture, Lithuanian Research Centre for Agriculture and Forestry \\ Kauno 30, Babtai, Kaunas distr., Lithuania \\ E-mail: n.rasiukeviciute@1sdi.lt
}

\begin{abstract}
Botrytis cinerea Pers.: Fr is an important strawberry disease-causing pathogen with a broad host range. Classical $B$. cinerea identification is complicated due to the lack of morphological polymorphism between species. The use of molecular tools helps to identify pathogens fast and accurately. This study aimed to determine Botrytis spp. isolates and evaluate the genetic diversity of grey mould population in Lithuania. During June-August of 2012-2014, 273 isolates were sampled from 12 different areas of Lithuania. All samples were isolated from infected fruits, and single-spore isolates were extracted. $B$. cinerea isolates were identified using $B$. cinerea species-specific primers

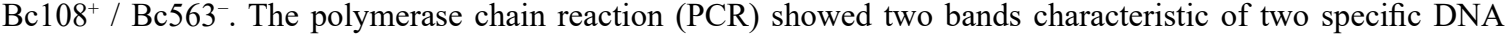
fragments of $B$. cinerea - upper and lower band of 360 and $480 \mathrm{bp}$, respectively. These two bands reflect pathogen genotype differentiation and could be used for cryptic species detection. The cryptic species analysis revealed that resistant group I accounted for $16.95 \%$ and sensitive group II for $83.05 \%$ of the Lithuanian collection of $B$. cinerea isolates. The precise identification of the $B$. cinerea cryptic species is important for the species-specific fungicide resistance and aggressiveness. Four microsatellite markers used in this study revealed genetic diversity of $B$. cinerea. The 158 isolates were identified as $B$. cinerea. The most polymorphic microsatellite marker was BC6 $(0.88)$ and the least polymorphic - BC7 (0.79). The isolates clustered into three genetic groups. The first group consisted of 45 strains, the second group of 15 and the third group of 4 isolates. Our data show genetic diversity within the Lithuanian population of $B$. cinerea. One of the management tools is recognition and identification of the pathogen which leads to optimal and efficient disease management.
\end{abstract}

Key words: grey mould, identification, pathogen, polymorphism.

\section{Introduction}

The strawberry is one of the most popular berry fruits in the world, including Lithuania. Winter hardiness is one of the limiting factor affecting plants overwintering and productivity. Despite, due to ripening time and fungal pathogens, strawberry decay losses can reach up to $40 \%$ or more (Uselis et al., 2008; Daugaard, 2014; Rugienius et al., 2016).

Fungal pathogens feature several life cycles and often occur in large parts of the world. The necrotrophic Botrytis cinerea Pers.: Fr. is one of the most important strawberry diseases all over the world with a with a broad host range. Botrytis spp. comprises 22 species and a large number of host-specific pathogens. $B$. cinerea is a fungal pathogen causing grey mould on more than 586 plant genera. The pathogen has the capability to develop an infection at a temperature range from $2^{\circ} \mathrm{C}$ to $28^{\circ} \mathrm{C}$ (optimal $20^{\circ} \mathrm{C}$ ) and leaf wetness periods above $80 \%$, which lasts more than 4 hours. It damages hundreds of plants causing grey mould and infects strawberry leaves, fruits, flowers, petioles, stems and often starts early as blossom blight (Williamson et al., 2007; Fournier, Giraud, 2008; Walker, Fournier, 2013; Carisse, 2016; Dewey, Grant-Downton, 2016; Elad et al., 2016).
$B$. cinerea is an important strawberry diseasecausing pathogen, which reduces yield and causes postharvest losses (Williamson et al., 2007; Elad et al., 2016; Rasiukevičiūte, 2016). The primary strategy of selecting specific plant protection system is knowledge about the pathogen. The lack of difference among Botrytis spp. by classical morphological and cultural methods demands a new solution. Molecular tools help to identify Botrytis spp. fast and accurately (Williamson et al., 2007; De Miccolis Angelini et al., 2016; Carisse, 2016; Dewey, Grant-Downton, 2016; Elad, 2016; Elad et al., 2016). The microsatellite with specific genetic markers enables fast evaluation of pathogen polymorphism (Fournier et al., 2003; 2005; Fournier, Giraud, 2008; De Miccolis Angelini et al., 2016; Walker, 2016).

Genetic studies revealed that $B$. cinerea is grouped into two cryptic phylogenetic species. Cryptic species are also related to resistance to the fungicide fenhexamid: group I is resistant, and group II is sensitive. The precise identification of the $B$. cinerea group is important for the species-specific fungicide resistance and aggressiveness (Fournier et al., 2005; Fournier, Giraud, 2008; Fournier et al., 2013; De Miccolis Angelini et al.,

Please use the following format when citing the article:

Rasiukevičiūtė N., Rugienius R., Šikšnianienè J. B. 2018. Genetic diversity of Botrytis cinerea from strawberry in Lithuania. Zemdirbyste-Agriculture, 105 (3): 265-270 DOI 10.13080/z-a.2018.105.034 
2016; Rasiukevičiūte, 2016; Walker, 2016). Group I is called B. pseudocinerea and group II - B. cinerea sensu stricto. They have similar morphological features except that asexual spores in group II are significantly smaller than in group I. They occupy the same environment and often parasitize the same host, but B. pseudocinerea is more frequent on dead flower parts in the spring (Fournier et al., 2005; Fournier, Giraud, 2008; Walker et al., 2011; Fournier et al., 2013; Carisse, 2016; Elad, 2016; Elad et al., 2016; Walker, 2016).

The biology of the pathogen comprises a number of interactions between host, pathogen and environment which influence disease development (Carisse, 2016; Elad, 2016; Elad et al., 2016). The populations of $B$. cinerea are highly diverse and deeply structured according to the host plant and the cropping system (Walker, Fournier, 2013). Control of strawberry grey mould is based on integrated plant protection with the use of fungicides. Therefore, it is important to understand the pathogen population structure and distribution for optimal use of fungicides. Valiuškaitė et al. (2010) evaluated Botrytis spp. Lithuanian population from different hosts. The research revealed that within Botrytis spp. population there was no obvious specificity within the geographical location or plant hosts. The aim of this study was to identify Botrytis spp. isolates and evaluate the genetic diversity in grey mould population in Lithuania.

\section{Materials and methods}

Isolates. During June-August of 2012-2014, 273 isolates were sampled from 12 different areas of Lithuania (Table 1). All samples were taken from infected strawberry Fragaria $\times$ ananassa Duch. fruits using a sterilized needle; then isolates were cultured 7 days at 22 $\pm 2^{\circ} \mathrm{C}$ on potato dextrose agar (PDA) (MERK, Germany). The Botrytis spp. growing mycelium was transferred to new PDA and cultured again for 7 days at $22 \pm 2{ }^{\circ} \mathrm{C}$ in the dark. This step was repeated twice to purify the culture, then single-spore isolates were extracted. Single-spore isolate collections were stored on PDA at $4{ }^{\circ} \mathrm{C}$.

Table 1. Botrytis spp. isolates from strawberry, 2012-2014

\begin{tabular}{|c|c|c|c|}
\hline Area & Year & Cultivar & $\begin{array}{l}\text { Number } \\
\text { of isolates }\end{array}$ \\
\hline Prienai dist. & 2014 & Marmolada, Sonata, Felicita & 17 \\
\hline Prienai dist., Klebiškis & 2014 & Unknown & 6 \\
\hline Šiauliai dist., Adomiškiai & 2014 & Malvina & 20 \\
\hline Kaunas dist. & 2012 & Unknown & 1 \\
\hline Kaunas & 2012 & Elkat & 4 \\
\hline Kaunas & 2013 & Elkat & 5 \\
\hline Kaunas dist., Babtai & 2012 & Darselect, Elkat & 7 \\
\hline Kaunas dist., Babtai & 2013 & Darselect, Venta, Elkat & 82 \\
\hline Kaunas dist., Babtai & 2014 & Darselect, Elkat & 10 \\
\hline Šiauliai dist., Kantminai & 2014 & Darselect, Elene, Syria & 22 \\
\hline Šiauliai dist., Maniušiai & 2014 & Sonata, Syria & 30 \\
\hline Radviliškis dist., Velžys & 2014 & Pandora, Sonata & 19 \\
\hline Panevėžys dist., Sodeliškiai & 2014 & Selvik, Rumba, Elkat, Felicita, Filut & 19 \\
\hline Kèdainiai dist., Dotnuva & 2014 & Senga Sengana & 7 \\
\hline Kèdainiai dist., Labūnava & 2014 & Syria, Vikat, Pegasus, Pandora & 24 \\
\hline \multicolumn{3}{|r|}{ 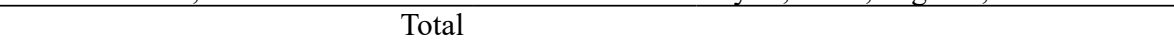 } & 273 \\
\hline
\end{tabular}

DNA isolation. Botrytis spp. single-spore isolates were grown on PDA Petri dishes at $22 \pm 2{ }^{\circ} \mathrm{C}$ in the dark. After 7 days of incubation, germinating mycelia were collected and pulverised in liquid nitrogen. For each of the 273 isolates, DNA was extracted using a Thermo Scientific Genomic DNA Purification Kit (Thermo Fisher Scientific, Lithuania). DNA was dissolved in $100 \mu \mathrm{l}$ of $1 \times$ TE buffer and stored at $-20^{\circ} \mathrm{C}$. DNA concentration was measured with a NanoDrop 1000 spectrometer (Thermo Fisher Scientific, USA).

Identification. B. cinerea Pers.: Fr isolates were identified using $B$. cinerea species-specific primers

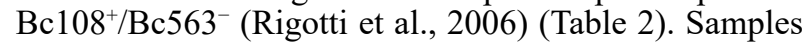
were incubated in a thermoshaker Grant Bio PHMT (Grant Instruments, UK). Polymerase chain reaction (PCR) amplification was performed in a $20 \mu \mathrm{l}$ reaction volume containing: $2.5 \mu \mathrm{l} 10 \times$ Tag buffer, $2 \mu \mathrm{l}$ dNTP Mix $2 \mathrm{mM}$ each, $0.1 \mu \mathrm{l}$ of each primer $\left(\mathrm{Bc} 108^{+}\right.$and $\mathrm{Bc} 63^{-}$), $1.5 \mu \mathrm{l} 25 \mathrm{mM} \mathrm{MgCl}_{2}, 1 \mu \mathrm{l}$ of DNA (adjusted to $\left.200 \mathrm{ng} \mu \mathrm{l}^{-1}\right), 0.1 \mu \mathrm{l}$ Taq DNA polymerase recombinant,

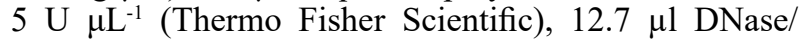
RNase-free water. PCR reactions were performed in a Mastercycler (Eppendorf, Germany). PCR amplification was performed as in Khazaeli et al. (2010). PCR reactions were repeated twice and electrophoresis was resolved on a 1.5 percent agarose in $1 \times$ TAE buffer gel and visualised by staining with Ethidium bromide (CarlRoth, Germany).
The used marker used is GeneRuler DNA Ladder mix $1 \mathrm{~kb}$ (Thermo Fisher Scientific).

Cryptic species. PCR for cryptic species detection was performed with specific primers $262 / 520 \mathrm{~L}$ according to the protocol of Fournier et al. (2003) (Table 2). PCR amplification was performed in a $20 \mu \mathrm{l}$ reaction volume containing $1.5 \mu \mathrm{l}$ of DNA, $2 \mu \mathrm{l} 10 \times \mathrm{PCR}$ buffer (Sigma Aldrich, USA), $12.1 \mu$ l DNase/RNasefree water, $1 \mu \mathrm{MgCl}_{2}$ (Thermo Fisher Scientific), $0.4 \mu \mathrm{l}$ $10 \mathrm{mM}$ dNTP (Thermo Fisher Scientific), $1 \mu \mathrm{l}$ REDTag Genomic DNA Polymerase (concentration 1 unit $\mu \mathrm{L}^{-1}$ ), $1 \mu \mathrm{l}$ of each 262 and 520L primer. PCR reactions were performed in a Mastercycler (Eppendorf). The program applied for amplification was as follows: 1 cycle of $5 \mathrm{~min}$ at $94^{\circ} \mathrm{C}, 35$ cycles of $30 \mathrm{~s}$ at $94^{\circ} \mathrm{C}, 1 \mathrm{~min} 30 \mathrm{~s}$ at $55^{\circ} \mathrm{C}$, $1 \mathrm{~min}$ at $72^{\circ} \mathrm{C}$; 1 cycle of final extension for $5 \mathrm{~min}$ at $72^{\circ} \mathrm{C}$ (Fournier et al., 2003). Digestion was made directly after PCR amplification. The reaction volume was $31 \mu \mathrm{l}$ containing: $10 \mu \mathrm{l}$ of PCR reaction mixture, $18 \mu \mathrm{l}$ DNase/ RNase-free water, $2 \mu \mathrm{l} 10 \times$ Tango buffer (Thermo Fisher Scientific), $\left.1 \mu \mathrm{l} \mathrm{HhaI} \mathrm{(10} \mathrm{U}^{\mathrm{l}^{-1}}\right)$ enzyme (Thermo Fisher Scientific). Digestion was made in water-thermostat (Biosan, Latvia) for 2 hours at $37^{\circ} \mathrm{C}$ and directly after digestion reaction was inactivated with $1.24 \mu \mathrm{l} 0.5 \mathrm{M}$ EDTA (20 nM final concentration). The product was amplified at $601 \mathrm{bp}$ (group I) and $517 \mathrm{bp}$ (group II) (Fournier et al., 2003). PCR reactions were repeated 
Table 2. Primer sequences used for analysis of Botrytis cinerea microsatellites

\begin{tabular}{|c|c|c|c|}
\hline Primer & Primer sequence & $\begin{array}{c}\text { Size } \\
\text { bp }\end{array}$ & Reference \\
\hline$\overline{\mathrm{Bc} 108^{+}}$ & F 5'-ACCCGCACCTAATTCGTCAAC-3' & \multirow[b]{2}{*}{360,480} & \multirow[b]{2}{*}{ Rigotti et al., 2006} \\
\hline $\mathrm{Bc} 563^{-}$ & R 5'-GGGTCTTCGATACGGGAGAA-3' & & \\
\hline $\mathrm{Bc} 2-\mathrm{F}$ & FAM 5'CATACACGTATTTCTTCCAA3' & \multirow{2}{*}{200} & \multirow{8}{*}{ Fournier et al., 2002} \\
\hline $\mathrm{Bc} 2-\mathrm{R}$ & 5’TTTACGAGTGTTTTTGTTAG3’' & & \\
\hline Bc6-F & HEX 5'ACTAGATTCGAGATTCAGTT3' & \multirow{2}{*}{$100,150,300$} & \\
\hline Bc6-R & 5’AAGGTGGTATGAGCGGTTTA3' & & \\
\hline Bc7-F & TAMRA 5'CCAGTTTCGAGGAGGTCCAC3' & \multirow{2}{*}{150} & \\
\hline $\mathrm{Bc} 7-\mathrm{R}$ & 5'GCCTTAGCGGATGTGAGGTA3' & & \\
\hline $\mathrm{Bc} 10-\mathrm{F}$ & ROX 5'TCCTCTTCCCTCCCATCAAC3' & \multirow{2}{*}{160,200} & \\
\hline $\mathrm{Bc} 10-\mathrm{R}$ & 5'GGATCTGCGTGGTTATGACG3' & & \\
\hline 262 & 5'AAGCCCTTCGATGTCTTGGA3' & \multirow{2}{*}{1172} & \multirow{2}{*}{ Fournier et al., 2003} \\
\hline $520 \mathrm{~L}$ & 5'ACGGATTCCGAACTAAGTAA3' & & \\
\hline
\end{tabular}

twice and electrophoresis resolved on a 1.5 percent agarose in $1 \times$ TAE buffer gel and visualised by staining with Ethidium bromide (CarlRoth, Germany). The used marker used is GeneRuler DNA Ladder mix $1 \mathrm{~kb}$ Ladder (Thermo Fisher Scientific).

Microsatellite analysis. Microsatellite single sequence repeat (SSR) analysis was performed using four of the nine microsatellite markers developed by Fournier et al. (2002). PCR amplifications were multiplexed. Microsatellite PCR amplification was performed in a $10 \mu \mathrm{l}$ reaction volume containing $1 \mu \mathrm{l}$ of DNA, $1 \mu \mathrm{l}$ PVP, $0.1 \mu \mathrm{l}$ DDT, $1 \mu \mathrm{l} 10 \times$ Tag buffer, $1 \mu \mathrm{d}$ dNTP Mix $2 \mathrm{mM}$ each, $0.7 \mu 125 \mathrm{mM} \mathrm{MgCl}, 0.05 \mu 1$ Taq DNA polymerase (concentration $5 \mathrm{U} \mu \mathrm{L}^{-1}$, recombinant) (Thermo Fisher Scientific), $4.65 \mu \mathrm{l}$ DNase/RNase-free water, $0.5 \mu \mathrm{l}$ of primer mix 1 or 2. Primer mix 1: BC2 and BC6; primer mix 2: BC7 and BC10 (Table 2). PCR reactions were performed in a Mastercycler (Eppendorf). The program applied for amplification was as follows: 1 cycle of $5 \mathrm{~min}$ at $95^{\circ} \mathrm{C}, 28$ cycles of $30 \mathrm{~s}$ at $95^{\circ} \mathrm{C}, 90 \mathrm{~s}$ at $59^{\circ} \mathrm{C}, 30 \mathrm{~s}$ at $72^{\circ} \mathrm{C} ; 1$ cycle of final extension for $30 \mathrm{~min}$ at $60^{\circ} \mathrm{C}$ (Fournier et al., 2003).

Fragments were separated in an automated single-capillary genetic analyser sequencer. Fragment analysis was performed using genetic analyser 3130 (Applied Biosystems, USA) using $36 \mathrm{~cm}$ capillary array and POP-7 polymer. Data were analysed using software GeneMapper, v.4.0 (Applied Biosystems).

Statistical analysis. The genetic distance matrix was calculated using the Nei and Li (1979) method and cluster analysis was conducted using the UPGMA (unweighted pair-group method with arithmetic mean) method. To test the reliability of the dendrograms, a bootstrap analysis with 1000 replications was performed.

\section{Results and discussion}

Pathogen identification. Based on phenotypical, ecological and genetic description, Botrytis cinerea is known as a highly variable species (Carisse, 2016; De Miccolis Angelini et al., 2016; Elad et al., 2016). The present study, using genetic markers, confirmed the occurrence of $B$. cinerea in Lithuania. The accurate identification and monitoring of the pathogen help to control it (De Miccolis Angelini et al., 2016; Elad, 2016; Elad et al., 2016; Rasiukevičiūte, 2016). Species-specific primers have been developed for $B$. cinerea detection (Rigotti et al., 2002; 2006). Several types of research revealed that $B$. cinerea population is extremely diverse (Fournier et al., 2003; 2005; Fournier, Giraud, 2008; Carisse, 2016; De Miccolis Angelini et al., 2016; Elad et al., 2016; Walker, 2016).
Therefore, in this study more than 270 Botrytis spp. samples from 12 different areas of Lithuania, collected in 2012-2014, were analysed to identify as B. cinerea. Fungi were isolated from infected strawberry fruits. The PCR is one of the methods which allow accurate species identification. Identifying species of fungi, the known DNA sequences can be used. Rigotti et al. (2002; 2006) have designed several specific primers, but in our study $\mathrm{Bc} 108^{+} / \mathrm{Bc} 563^{-}$was more accurate because it amplifies two different-size fragments.

The PCR of 273 isolates resulted that only 158 were identified as B. cinerea (Fig. 1). The primers $\mathrm{Bc} 108^{+} /$ $\mathrm{Bc} 563^{-}$gave two bands of DNA fragment of $B$. cinerea, upper band $360 \mathrm{bp}$ or lower $480 \mathrm{bp}$. These two bands reflect pathogen genotype differentiation and could be used for cryptic species detection (Rasiukevičiūtè, 2016). The data suggested that $7.59 \%$ of isolates belong to group I and $92.41 \%$ - to group II. These two groups reflect the pathogen response to the fungicide fenhexamid. Our data display that Rigotti et al. (2006) $\mathrm{Bc} 108^{+} / \mathrm{Bc} 563^{-}$ primers confirm not only $B$. cinerea but also specify cryptic species. Our data show that molecular markers are more useful in the detection of $B$. cinerea species. The molecular tools using species-specific primers helped us to identify isolates of $B$. cinerea precisely and rapidly.

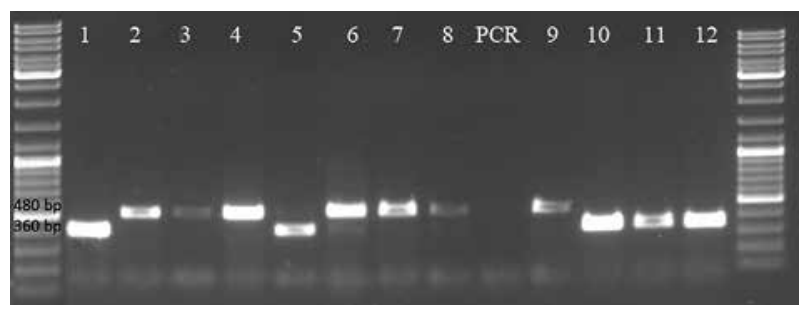

Amplified fragment 360 and $480 \mathrm{bp} ; 1-12$ - B. cinerea fragment, PCR - negative control (reaction mixture without pathogen DNA)

Figure 1. The electrophoretic profile of polymerase chain reaction (PCR) products of Botrytis cinerea isolates, obtained with primers $\mathrm{BC} 108^{+} / \mathrm{BC} 563^{-}$

We selected 59 isolates obtained from our study to identify these two distinct $B$. cinerea groups. The size of amplified group I band was $601 \mathrm{bp}$ and for group II $-517 \mathrm{bp}$. Isolates of group I are resistant to fenhexamid, whereas those of group II are sensitive (De Miccolis Angelini et al., 2016; Walker, 2016). Fournier et al. (2005) determined that group I and II represent $B$. cinerea cryptic species. Walker et al. (2011) have reported that group I is new species of Botrytis spp. named $B$. pseudocinerea. Our data revealed that among the 59 isolates predominant were sensitive to fenhexamid 
group II $-83.05 \%$ isolates and resistant group I - only $16.95 \%$ isolates (Table 3). Our data agree with other authors' findings that group II is predominant on infected fruits (Fournier et al., 2005; Wahab, 2015; Saito et al., 2016). Saito et al. (2016) found that $99.3 \%$ of isolates belonged to group II and only $0.7 \%$ - to group I. Martinez et al. (2008) also suggest that group II $(97.7 \%)$ is highly dominant over group I $(2.3 \%)$. Our data show that group II is prevailing in Lithuanian isolates. However, in our study we observed slightly more group I isolates than in the studies mentioned above. It is likely that the ratio of those groups is changing over time, due to intensive use of pesticides. Further studies and monitoring are required.

Table 3. Cryptic species of Botrytis cinerea, group I and II

\begin{tabular}{cccc}
\hline \multirow{2}{*}{ Origin } & Number & \multicolumn{2}{c}{ Group } \\
\cline { 3 - 4 } of isolates & I & II \\
\hline Babtai & 46 & 9 & 37 \\
Kaunas & 9 & 0 & 9 \\
Kaunas distr. & 4 & 1 & 3 \\
Total & 59 & 10 & 49 \\
\hline
\end{tabular}

Microsatellite analysis. A group of 67 $B$. cinerea isolates from different areas of Lithuania were analysed. All 67 B. cinerea isolates were completely genotyped using four microsatellites (Table 5). All examined microsatellite loci were polymorphic. The four microsatellite markers exhibited between 9 and 23 alleles, with an average of 13.25 alleles per marker in the analysed B. cinerea samples (Table 4). Fournier and Giraud (2008) found that the number of alleles varied from 3 to 6 . The most polymorphic microsatellite marker was BC6 $(\mathrm{PIC}=0.88)$ and the least polymorphic was BC7 (PIC $=0.79$ ). Our data show that polymorphism information content (PIC) was higher than in the study of Leyronas et al. (2015) $(\mathrm{PIC}=0.71)$. The observed heterozygosity varied from 0.02 to 0.61 with the average value of 0.24 . Expected heterozygosity value ranged from 0.81 to 0.89 with the average of 0.84 . Observed heterozygosity values were lower than expected heterozygosity in all investigated loci (Table 5). Compared with other studies, the mean expected heterozygosity was similar $\left(\mathrm{H}_{0}=\right.$ 0.894 ) to the one reported by Fekete et al. (2012) and higher $\left(\mathrm{H}_{0}=0.52-0.79\right)$ than that reported by Fournier and Giraud (2008), and by Assadollahi et al. (2013)

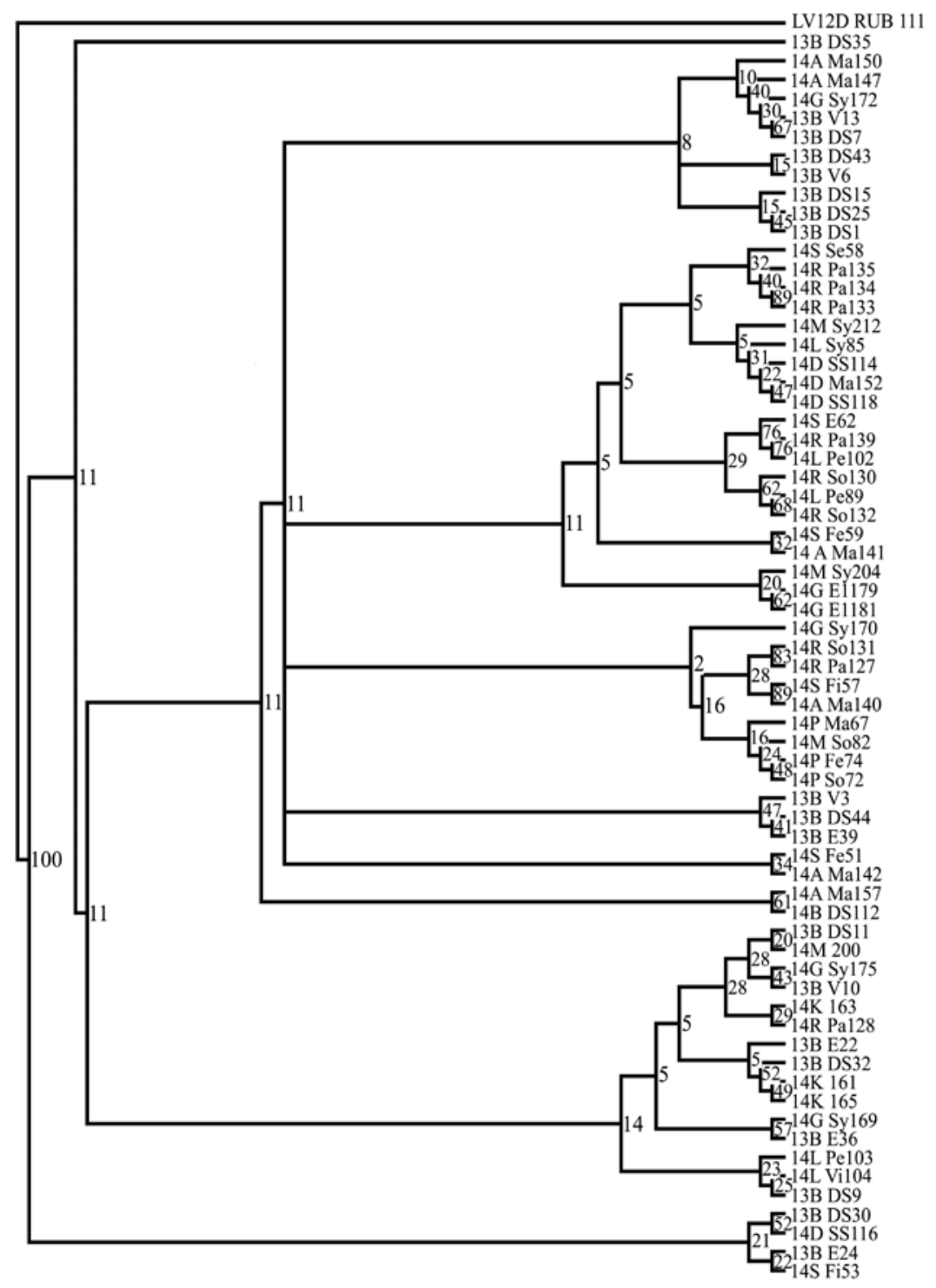

Note. Bootstrap frequencies were calculated with 1000 replicates.

Figure 2. Dendrogram of strawbery isolates from different agroecological regions, constructed using UPGMA algorithm 
$\left(\mathrm{H}_{0}=3.53\right)$. Fournier et al. (2013) found that observed heterozygosity ranged from 0.41 to 0.58 , which agrees with our results. Lower than expected heterozygosity shows high inbreeding occurrence among isolates. On the other hand, the high expected heterozygosity coincides with high genetic diversity of $B$. cinerea (Kumari et al., 2014; Corwin et al., 2016).

Table 5. Characterization of alleles from different agroecological regions of Lithuania

\begin{tabular}{ccccccc}
\hline No. & Marker & $\begin{array}{c}\text { Number } \\
\text { of alleles }\end{array}$ & $\begin{array}{c}\text { Allele size } \\
\text { range bp }\end{array}$ & $\mathrm{H}_{0}$ & $\mathrm{H}_{\mathrm{e}}$ & $\mathrm{PIC}$ \\
\hline 1 & BC2 & 9 & $144-174$ & 0.83 & 0.02 & 0.81 \\
3 & BC6 & 23 & $84-268$ & 0.89 & 0.61 & 0.88 \\
4 & BC7 & 12 & $109-133$ & 0.81 & 0.21 & 0.79 \\
5 & BC10 & 9 & $162-191$ & 0.82 & 0.12 & 0.80 \\
\hline Mean & & 13.25 & & 0.84 & 0.24 & 0.82 \\
\hline
\end{tabular}

$\mathrm{H}_{0}$ - expected heterozygosity, $\mathrm{H}_{\mathrm{e}}-$ observed heterozygosity, PIC - polymorphism information content

The dendrogram constructed by UPGMA illustrates the relationship among $B$. cinerea isolates, they were genotyped entirely using four microsatellite primer pairs (Fig. 2). The similarity between the isolates was computed as Nei's genetic identity (Nei, Li, 1979). Isolates tended to cluster into several groups.

The clustering of $B$. cinerea isolates from different regions of Lithuania was constructed using 67 different fragments. The $B$. cinerea strains clustered in three main clades, but two isolates were distant. One of the distant isolates was obtained from raspberry cultivar 'Gerakl' (LV12DRUB111) from Latvia. The second distant was from Babtai, isolated from strawberry cultivar 'Darselect' (13BDS35) in 2013. The first group consisted of 45 strains, the second group of 15 and the third group of 4 isolates. This one cluster (13BDS30, 14DSS116, 13BE24 and 14SFi53) is also quite distant from other two clusters. Fournier et al. (2013) have indicated that geographical origin of the isolates does not alternate genetic diversity of $B$. cinerea. Walker and Fournier (2013) found that genetic variation of $B$. cinerea from grapevine was structured by the cropping system combined with the host plant.

The data of our study show genetic diversity within the Lithuanian population of $B$. cinerea. The literature review also shows high genetic diversity of Botrytis spp., but the proportion of isolates sensitive and resistant to fenhexamid differs (Corwin et al., 2016; De Miccolis Angelini et al., 2016; Elad et al., 2016). The importance of $B$. cinerea as strawberry pathogen and its impact on yield require precise management. One of the management tools is recognition and identification of the pathogen. In Lithuania, the use of fenhexamid has never been allowed for strawberry disease control, but despite that our data show that $B$. cinerea group sensitive to it is prevailing in Lithuanian isolates. In our opinion, and according to the literature review, the pathogen could spread out with propagation material which could be from countries where this fungicide is allowed (Elad et al., 2016). Transfer of B. cinerea can be indirectly confirmed by the results of our research where some genetically distant isolates were detected (Fig. 2). Furthermore, the cryptic species of pathogen might differ in general or complex resistance to several pesticides. The molecular tools are an important implement showing that analyses of resistance of various host plants to different active ingredients of fungicides must be continued.

\section{Conclusions}

1. Polymerase chain reaction confirmed that among 273 isolates of Botrytis spp. 158 were identified as Botrytis cinerea Pers.: Fr. The primers BC108 $/ 8^{+}{ }^{3} 563^{-}$ are suitable not only for $B$. cinerea identification, but also for the detection of cryptic species.

2. Assessments of genetic diversity using microsatellite analysis revealed distinction within the Lithuanian population of $B$. cinerea. Polymorphic information values varied from 0.79 to 0.88 with an average of 0.82 . The $B$. cinerea strains clustered in three main groups with genetically distinct isolates.

Received 21122017 Accepted 26032018

\section{References}

1. Assadollahi M., Fekete E., Karaffa L., Flipphi M., Árnyasi M., Esmaeili M., Váczy K. Z., Sándor E. 2013. Comparison of Botrytis cinerea populations isolated from two open-field cultivated host plants. Microbiological Research, 168 (6): 379-388. https://doi.org/10.1016/j.micres.2012.12.008

2. Carisse O. 2016. Epidemiology and aerobiology of Botrytis spp. Fillinger S., Elad Y. (eds). Botrytis - the fungus, the pathogen and its management in agricultural systems. Springer, p. 127-148. https://doi.org/10.1007/978-3-319-23371-0 7

3. Corwin J. A., Subedy A., Eshbaugh R., Kliebenstein D. J. 2016. Expansive phenotypic landscape of Botrytis cinerea shows differential contribution of genetic diversity and plasticity. Molecular Plant-Microbe Interactions, 29 (4): 287-298. https://doi.org/10.1094/MPMI-09-15-0196-R

4. Daugaard H. 2000. Effect of cultural methods on the occurrence of grey mould (Botrytis cinerea Pers.) in strawberries. Biological Agriculture and Horticulture, 18 (1): 77-83. https://doi.org/10.1080/01448765.2000.9754866

5. De Miccolis Angelini R. M., Pollastro S., Faretra F. 2016. Genetics of Botrytis cinerea. Fillinger S., Elad Y. (eds). Botrytis - the fungus, the pathogen and its management in agricultural systems. Springer, p. 35-53. https://doi.org/10.1007/978-3-319-23371-0 3

6. Dewey (Molly) F. M., Grant-Downton R. 2016. Botrytis - biology, detection and quantification. Fillinger S., Elad Y. (eds). Botrytis - the fungus, the pathogen and its management in agricultural systems. Springer, p. 17-34.

7. Elad Y. 2016. Cultural and integrated control of Botrytis. Fillinger S., Elad Y. (eds). Botrytis - the fungus, the pathogen and its management in agricultural systems. Springer, p. 149-164. https://doi.org/10.1007/978-3-319-23371-0 8

8. Elad Y., Vivier M., Fillinger S. 2016. Botrytis, the good, the bad and the ugly. Fillinger S., Elad Y. (eds). Botrytis - the fungus, the pathogen and its management in agricultural systems. Springer, p. $1-15$. https://doi.org/10.1007/978-3-319-23371-0 1

9. Fekete E., Fekete E., Irinyi L., Karaffa L., Arnyasi M., Asadollagi M., Sandor E. 2012. Genetic diversity of a Botrytis cinerea cryptic species complex in Hungary. Microbiological Research, 167 (5): 283-291. https://doi.org/10.1016/j.micres.2011.10.006

10. Fournier E., Giraud T. 2008. Sympatric genetic differentiation of a generalist pathogenic fungus, Botrytis cinerea, on two different host plants, grapevine and bramble. Journal of Evolutionary Biology, 21 (1): 122-132. https://doi.org/10.1111/j.1420-9101.2007.01462.x

11. Fournier E., Giraud T., Loiseau A., Vautrin D., Estoup A., Solignac M., Cornuet J. M., Brygoo Y. 2002. Characterization of nine polymorphic microsatellite loci in the fungus Botrytis cinerea (Ascomycota). Molecular Ecology Notes, 2: 253-255. https://doi.org/10.1046/j.1471-8286.2002.00207.x

12. Fournier E., Levis C., Fortini D., Leroux P., Giraud T., Brygoo Y. 2003. Characterization of Bc-hch, the Botrytis cinerea homolog of the Neurospora crassa het-c vegetative incompatibility locus, and its use as a population marker. Mycologia, 95 (2): 251-261. https://doi.org/10.1080/15572536.2004.11833110 
13. Fournier E., Giraud T., Albertini A., Brygoo Y. 2005. Partition of the Botrytis cinerea complex in France using multiple gene genealogies. Mycologia, 97 (6): 1251-1267. https://doi.org/10.1080/15572536.2006.11832734

14. Fournier E., Gladieux P., Giraud T. 2013. The 'Dr Jekyll and Mr Hyde fungus': noble rot versus gray mold symptoms of Botrytis cinerea on grapes. Evolutionary Applications, 6 (6): 960-969. https://doi.org/10.1111/eva.12079

15. Khazaeli P., Zamanizadeh H., Morid B., Bayat H. 2010. Morphological and molecular identification of Botrytis cinerea causal agent of gray mold in rose greenhouses in Central Regions of Iran. International Journal of Agricultural Science and Research, 1 (1): 19-24.

16. Kumari S., Tayal P., Sharma E., Kapoor R. 2014. Analyses of genetic and pathogenic variability among Botrytis cinerea isolates. Microbiological Research, 169 (11): 862-872. https://doi.org/10.1016/j.micres.2014.02.012

17. Leyronas C., Halkett F., Nicot P. C. 2015. Relationship between the genetic characteristics of Botrytis sp. airborne inoculum and meteorological parameters, seasons and the origin of air masses. Aerobiologia, 31 (3): 367-380. https://doi.org/10.1007/s10453-015-9370-x

18. Martinez F., Corio-Costet M. F., Levis C., Coarer M., Fermaud M. 2008. New PCR primers applied to characterize distribution of Botrytis cinerea populations in French vineyards. Vitis, 47 (4): 217-226.

19. Nei M., Li W. H. 1979. Mathematical model for studying genetic variation in terms of restriction endonucleases. Proceedings of the National Academy of Sciences, 76 (10): 5269-5273. https://doi.org/10.1073/pnas.76.10.5269

20. Rasiukevičiūtè N. 2016. Genetic and phenotypic diversity of Botrytis spp. from strawberry and onion, diseases forecasting and control: doctoral dissertation. Lithuanian Research Centre for Agriculture and Forestry, 189 p. (in Lithuanian).

21. Rugienius R., Šnipaitiene L., Stanienė G., Šikšnianienė J. B., Haimi P., Baniulis D., Frercks B., Pranckietis V., Lukoševičiūtė V., Stanys V. 2016. Cold acclimation efficiency of different Prunus and Fragaria species and cultivars in vitro. Zemdirbyste-Agriculture, 103 (2): 207-214. https://doi.org/10.13080/z-a.2016.103.027

22. Rigotti S., Gindro K., Richter H., Viret O. 2002. Characterization of molecular markers for specific and sensitive detection of Botrytis cinerea Pers.: Fr. in strawberry (Fragaria $\times$ ananassa Duch.) using PCR. FEMS Microbiology Letters, 209: 169-174.

https://doi.org/10.1016/S0378-1097(02)00491-3

23. Rigotti S., Viret O., Gindro K. 2006. Two new primers highly specific for the detection of Botrytis cinerea Pers.: Fr. Phytopathologia Mediterranea, 45: 253-260.

24. Saito S., Margosan D., Michailides T. J., Xiao C. L. 2016. Botrytis californica, a new cryptic species in the $B$. cinerea species complex causing gray mold in blueberries and table grapes. Mycologia, 108 (2): 330-343. https://doi.org/10.3852/15-165

25. Uselis N., Lanauskas J., Zalatorius V., Duchovskis P., Brazaityte A., Urbonavičiūtè A. 2008. Evaluation of the methods of soil cultivation growing dessert strawberries in beds. Sodininkystė ir daržininkystè, 27 (2): 295-305.

26. Valiuškaitė A., Survilienė E., Baniulis D. 2010. Genetic diversity and pathogenicity traits of Botrytis spp. isolated from horticultural hosts. Zemdirbyste-Agriculture, 97 (4): 85-90.

27. Wahab H. A. 2015. Characterization of Egyptian Botrytis cinerea isolates from different host plants. Advances in Microbiology, 5: 177-189. https://doi.org/10.4236/aim.2015.53017

28. Walker A. S. 2016. Diversity within and between species of Botrytis. Fillinger S., Elad Y. (eds). Botrytis - the fungus, the pathogen and its management in agricultural systems. Springer, p. 91-125.

https://doi.org/10.1007/978-3-319-23371-0 6

29. Walker A. S., Fournier E. 2013. Habitat- and host-specific differentiation in the multihost pathogen Botrytis cinerea and evidence for fungicide selection in populations. Dehne H. W. et al. (eds). Modern Fungicides and Antifungal Compounds VII. Deutsche Phytomedizinische Gesellschaft, Braunschweig, p. 167-172.

30. Walker A. S., Gautier A., Confais J., Martinho D., Viaud M., Le Pêcheur P., Dupont J., Fournier E. 2011. Botrytis pseudocinerea, a new cryptic species causing gray mold in French vineyards in sympatry with Botrytis cinerea. Phytopathology, 101: 1433-1445. https://doi.org/10.1094/PHYTO-04-11-0104

31. Williamson B., Tudzynski B., Tudzynski P., Van Kan I. A. L. 2007. Botrytis cinerea: the cause of grey mould disease. Molecular Plant Pathology, 8 (5): 561-580. https://doi.org/10.1111/j.1364-3703.2007.00417.x

ISSN 1392-3196 / e-ISSN 2335-8947

Zemdirbyste-Agriculture, vol. 105, No. 3 (2018), p. 265-270

DOI 10.13080/z-a.2018.105.034

\title{
Botrytis cinerea patogeno, išskirto iš braškių, genetinè îvairovė Lietuvoje
}

\author{
N. Rasiukevičiūtè, R. Rugienius, J. B. Šikšnianienè \\ Lietuvos agrarinių ir miškų mokslų centro Sodininkystès ir daržininkystès institutas
}

\section{Santrauka}

Botrytis cinerea Pers.: Fr yra svarbus patogenas, sukeliantis braškiu ligas, turintis daug augalu šeimininku. Tradicinis $B$. cinerea indentifikavimas ne visada yra tikslus dẻl patogeno rūšių morfologinių požymių panašumo, todèl pastaruoju metu, siekiant ji tiksliau apibūdinti, atliekami molekuliniai tyrimai. Tyrimo tikslas - identifikuoti Botrytis spp. izoliatus ir ịvertinti jų genetinius skirtumus kekerinio puvinio populiacijoje Lietuvoje. 2012-2014 m. birželio-rugpjūčio mènesiais surinkti 273 izoliatai iš dvylikos Lietuvos vietovių. Visi mèginiai išskirti iš patogeno pažeistų uogų, ir iš jų išskirtos izoliatų monokultūros. $B$. cinerea identifikuoti parinkti rūšiai būdingi pradmenys $\mathrm{Bc} 108^{+}$ir Bc563-. Atlikus izoliatu polimerazès grandininès reakcijos (PGR) analize gauti du $B$. cinerea rūšiai būdingi DNR fragmentai, kurie amplifikavo 360 ir 480 bp fragmentus. Šie fragmentai atskleidžia patogeno genotipo skirtumus ir gali būti naudojami siekiant nustatyti filogenetiniu grupes. Filogenetiniu tyrimu analizè parodè, kad $B$. cinerea lietuviškoje izoliatų kolekcijoje atsparių I grupės buvo 16,95 \%, jautrių II grupès $-83,05 \%$. Tikslus $B$. cinerea filogenetinių grupiu nustatymas yra svarbus dèl rūšies atsparumo tam tikriems fungicidams ir jo agresyvumo. Mikrosatelitų analizė atlikta naudojant 4 skirtingas pradmenų poras. Nustatyta, kad 158 izoliatai yra B. cinerea. Pats informatyviausias pradmuo buvo BC6 $(0,88)$, mažiausiai informatyvus - BC7 $(0,79)$. Dendrogramoje izoliatai pasiskirste $i ̣$ tris pagrindines grupes. Pirmoje grupeje esmingai atsiskyre 45, antroje -15 , trečioje - 4 izoliatai. Tyrimo duomenys rodo, $\operatorname{kad} B$. cinerea populiacijai Lietuvoje yra būdinga genetinè ịvairovè. Viena iš patogeno kontrolès priemonių yra jo atpažinimas ir tikslus identifikavimas.

Reikšminiai žodžiai: identifikavimas, kekerinis puvinys, patogenas, polimorfizmas. 